\title{
Changes in plant debris and carbon stocks across a subalpine forest successional series
}

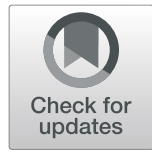

\author{
Zhihui Wang ${ }^{1}$, Lianjun Zhao ${ }^{2}$, Yi Bai ${ }^{1}$, Fei Li ${ }^{1}$, Jianfeng Hou' ${ }^{1}$ Xuqing $\mathrm{Li}^{1}$, Yurui Jiang ${ }^{1}$, Yuyue Deng ${ }^{1}$, \\ Bingqian Zheng ${ }^{1}$ and Wanqin Yang ${ }^{1 *}$
}

\begin{abstract}
Background: As a structurally and functionally important component in forest ecosystems, plant debris plays a crucial role in the global carbon cycle. Although it is well known that plant debris stocks vary greatly with tree species composition, forest type, forest origin, and stand age, simultaneous investigation on the changes in woody and non-woody debris biomass and their carbon stock with forest succession has not been reported. Therefore, woody and non-woody debris and carbon stocks were investigated across a subalpine forest successional gradient in Wanglang National Nature Reserve on the eastern Qinghai-Tibet Plateau.
\end{abstract}

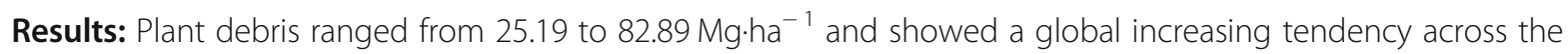
subalpine forest successional series except for decreasing at the $\$ 4$ successional stage. Accordingly, the ratios of woody to non-woody debris stocks ranged from 26.58 to 208.89, and the highest and lowest ratios of woody to non-woody debris stocks were respectively observed in mid-successional coniferous forest and shrub forest, implying that woody debris dominates the plant debris. In particular, the ratios of coarse to fine woody debris stocks varied greatly with the successional stage, and the highest and lowest ratios were found in later and earlier successional subalpine forests, respectively. Furthermore, the woody debris stock varied greatly with diameter size, and larger diameter woody debris dominated the plant debris. Correspondingly, the carbon stock of plant debris

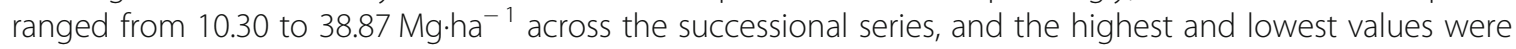
observed in the mid-coniferous stage and shrub forest stage, respectively. Most importantly, the carbon stored in coarse woody debris in later successional forests was four times higher than in earlier successional forests.

Conclusions: The stock and role of woody debris, particularly coarse woody debris, varied greatly with the forest successional stage and dominated the carbon cycle in the subalpine forest ecosystem. Thus, preserving coarse woody debris is a critical strategy for sustainable forest management.

Keywords: Coarse woody debris, Fine woody debris, Forest successional series, Later successional stage, Earlier successional stage, Log decay class, Diameter size

\section{Introduction}

Plant debris consists of woody debris (WD) and nonwoody debris (NWD), both of which play crucial roles not only in nutrient cycling and biodiversity conservation but also in the global carbon cycle (Pan et al. 2011; Zhu et al. 2017). In particular, WD includes fine woody debris (FWD) and coarse woody debris (CWD) (Harmon

\footnotetext{
* Correspondence: scyangwa@163.com

${ }^{1}$ School of Life Sciences, Taizhou University, Taizhou 318000, China

Full list of author information is available at the end of the article
}

et al. 1986), and the latter accounts for ca. $20 \%-30 \%$ of global woody biomass (Pan et al. 2011). CWD plays crucial roles in conserving biodiversity, forest regeneration, global carbon sinks, and soil development (Iwashita et al. 2013; Russell et al. 2015; Błońska et al. 2017; Prescott et al. 2017). Previous investigations have documented that WD and NWD stocks vary greatly with tree species composition (Raich et al. 2007; Wang et al., 2019), forest type (Moreira et al. 2019), forest origin (Hagemann et al. 2010; Suzuki et al. 2019), and stand

\section{Springer Open}

(- The Author(s). 2021 Open Access This article is licensed under a Creative Commons Attribution 4.0 International License, which permits use, sharing, adaptation, distribution and reproduction in any medium or format, as long as you give appropriate credit to the original author(s) and the source, provide a link to the Creative Commons licence, and indicate if changes were made. The images or other third party material in this article are included in the article's Creative Commons licence, unless indicated otherwise in a credit line to the material. If material is not included in the article's Creative Commons licence and your intended use is not permitted by statutory regulation or exceeds the permitted use, you will need to obtain permission directly from the copyright holder. To view a copy of this licence, visit http://creativecommons.org/licenses/by/4.0/. 
age (Sefidi 2010; Schilling et al. 2016). Most importantly, the rate of plant debris decomposition varies greatly with debris type (Cornwell et al. 2009; Harmon et al. 2013). FWD and NWD, such as foliar litter, decompose faster than CWD (Müller-Using and Bartsch 2009; Berbeco et al. 2012). Additionally, plant debris decomposition differs among tree species, and lower-density WD decomposes faster (Shorohova and Kapitsa 2016; Guo et al. 2020). The above description implies that the composition and proportion of plant debris might control forest regeneration, biodiversity nursing, soil and water conservation, and the cycling of carbon and nutrients. Thereby, an investigation of the changes in plant debris stock characteristics with tree species composition determined by forest type is crucial to understand the process and function of forest ecosystems.

In natural or unmanaged forests, forest succession is an important factor affecting the forest type and species diversity (Lebrija-Trejos et al. 2010; West et al. 2012; Taylor et al. 2020). Meanwhile, the input of plant debris is determined by the death or falling of aboveground species (Tritton 1981; Sturtevant et al. 1997). As a result, forest succession may affect the composition and stock of plant debris through the following aspects. First, the stock and composition of plant debris would vary to some degree with forest succession due to the differences in tree species composition and tree longevity at different succession stages. For instance, litter production and dynamics significantly vary with overstory tree species composition in lowland Costa Rica (Raich et al. 2007); forest type determines the species composition and CWD stock (Moreira et al. 2019). Second, tree species in the earlier succession stages may be more susceptible to disturbance and generate more CWD (Brassard and Chen, 2008). However, higher and lower stocks of WD have been observed at the later and earlier succession stages due to differential WD decomposition rates (Carmona et al. 2002). Zhu et al. (2017) have shown that the biomass and $\mathrm{C}$ storage of CWD may increase with forest succession, while a "U-shape" trend of CWD was observed along the forest successional gradient by Sefidi (2010). Idol et al. (2001) have shown a significant decrease in volume and mass of woody debris from recently harvested to mature stands. Together, the changes in plant debris with forest succession remain uncertain. Thereby, investigating the changes in plant debris stock across forest successional series will help us better understand the function of plant debris in forest ecosystems.

In theory, the stock and composition of plant debris depend greatly on the WD decomposition, particularly that of CWD (Zell et al. 2009). The decay rates of WD and NWD vary with tree species and diameter class (Cornwell et al. 2009; Harmon et al. 2013), while tree species composition is determined mainly by the succession stage (Taylor et al. 2020). Thus, forest succession development may affect the distribution of plant debris decay classes and diameter classes through the following aspects. On the one hand, CWD at earlier successional stages might decompose faster than those at later succession stages due to tree species at earlier successional stages have shorter life cycles and lower CWD quality (Puyravaud et al. 2003). For instance, the CWD of broad-leaved species decomposes faster (Yatskov et al. 2003); additionally, the CWD of angiosperms decomposes faster than that of gymnosperms (Herrmann et al. 2015). On the other hand, the CWD in the earlier successional forests usually have smaller diameters (Ott et al. 2006), while in the later succession, the CWD usually have larger diameters (Vanninen et al. 1996). Generally, larger-diameter CWD decomposes slower than smaller-diameter CWD (Harmon et al. 2013). Thus, characterizing the stocks and proportions of different decay and diameter classes at different successional stages is essential for understanding the nutrient dynamics of plant debris stock and predicting forest succession rate. However, little information is available on CWD stock changes with decay and diameter classes across forest successional series.

Plant debris represents an essential carbon pool and strongly influences on the structures and carbon dynamics in the forest ecosystems (Harmon et al. 1986). The impacts of various driving forces on CWD carbon stocks at the local scale have been widely investigated (e.g., Hall et al. 2006; Woodall and Liknes 2008; Kurz et al. 2009; Jonsson et al. 2011; Woodall et al. 2013). However, only a few studies have evaluated the dependency between the carbon storages of NWD and the stages of succession (Zhang et al. 2011). Furthermore, compared with carbon stocks in live biomass or soil, the $\mathrm{C}$ budgets in WD and NWD production and turnover at different forest succession stages have not been simultaneously investigated. Consequently, a comprehensive assessment of the carbon budget and the relative contributions of WD and NWD to the carbon budget across forest successional series are critically important for understanding the significance of plant debris in carbon sinks in forest ecosystems.

To understand the changes in the composition, biomass, and carbon stock of plant debris with forest succession, NWD, FWD, and CWD with different diameter classes and decay classes were investigated across a subalpine forest successional series in Wanglang National Nature Reserve on the eastern Qinghai-Tibet Plateau and the upper reaches of the Yangtze River. This region is the main body of China's second largest forest area and plays paramount roles not only in holding freshwater, conserving water, and soil and nursing 
biodiversity but also in the global carbon cycle (Liu 2002; Tan et al. 2014). Subalpine forest communities at different successional stages are observed in the subalpine forest region on the eastern Qinghai-Tibet Plateau due to long-term natural disturbance and the commercial logging of natural forests since the 1950s (Yang et al. 1992). Although the WD stock from the gap center to the closed canopy in an over-mature subalpine coniferous forest (Xiao et al. 2016), the water storage potential of WD (Wang et al. 2016), and the changes in microbial biomass and epixylic plant diversity with decay classes (Wang et al. 2017; Chang et al. 2019) have been widely investigated in this region, little attention has been given to the changes in the composition, biomass stock and carbon storage of plant debris with forest succession. Therefore, we hypothesized that (1) plant debris stocks would increase from the earlier successional stage to the later succession stage in the subalpine forest region, (2) the stocks and proportions of different decay and diameter classes should differ at different successional stages, and (3) the $\mathrm{C}$ stock of plant debris would increase across the forest succession. The objectives were to (1) investigate the changes in plant debris stocks across the forest successional series located in the subalpine forest region, (2) elucidate the stocks and proportion of different decay and diameter classes at different successional stages, and (3) assess the carbon budget and the relative contributions of CWD with different decay classes and diameter classes to the carbon budget across the forest successional series. These results could help us better understand the function and significance of plant debris in carbon sinks in forest ecosystems and provide clear insight into the preservation of CWD, which is a critical strategy for sustainable forest management in the subalpine forest on the eastern QinghaiTibet Plateau.

\section{Materials and methods Field description}

The study region is located in the Wanglang National Nature Reserve $\left(32^{\circ} 49^{\prime}-33^{\circ} 02^{\prime} \mathrm{N}, 1^{\circ} 3^{\circ} 55^{\prime}-104^{\circ} 10^{\prime} \mathrm{E}\right.$; 2300-4983 m a.s.l.), which is situating in Pingwu County, Sichuan, Southwest China (Fig. A1). The region is a transitional area between the Tibetan Plateau and the Sichuan Basin. The annual precipitation is approximately $859.9 \mathrm{~mm}$, and the annual mean temperature is approximately $2.9^{\circ} \mathrm{C}$, with maximum and minimum temperatures of $26.2{ }^{\circ} \mathrm{C}$ and $-17.8{ }^{\circ} \mathrm{C}$, respectively (Zhang et al. 2011). The tree canopy is dominated by Abies faxoniana, Picea purpurea, Sabina saltuaria, Betula platyphylla, and B. albo-sinensis. The understory shrubs are dominated by Salix wallichiana, Hippophae rhamnoides, Rhododendron lapponicum, Lonicera spp., Sorbus rufopilosa, and Rosa sweginzowii. The herbaceous layer is dominated by Cacalia palmatisecta, Cyperaceae, Poa pratensis, and others (Taylor et al. 2006). The moss layer is dominated by Thuidium cymbifolium, Hylocomium splendens, Mnium heterophyllum, and Phaeoceros laevis (Li et al. 2012).

\section{Experimental design}

Based on our previous visits and investigations on forest vegetation and plant debris in Wanglang National $\mathrm{Na}$ ture Reserve, we divided the different forest types into six succession stages according to Zhang et al. (2011) and through interviews with local supervisors. S1 successional stage is dominated by shrubs (e.g., H. rhamnoides), S2 successional stage is dominated by deciduous broadleaved species (e.g., Betula), S3 successional stage is dominated by deciduous broadleaved (Betula) and coniferous (A. faxoniana) mixed forest and later successional stages (S4, S5, and S6) are all dominated by coniferous species. Here $\mathrm{S} 4$ represents the earlier coniferous successional stage (A. faxoniana and $P$. purpurea); S5 represents the middle coniferous successional stage $(A$. faxoniana); S6 represents the mature coniferous successional stage ( $P$. purpurea). The six successional forests are widely distributed in the subalpine forest region (Fig. A1). Site information and specific characteristics of each successional stage are recorded in Table A1.

\section{Sampling method}

Woody debris was classified into CWD with a diameter $\geq 10 \mathrm{~cm}$ and FWD with a diameter of $2 \mathrm{~cm} \leq \mathrm{d}<10$ cm (Ward and Aumen 1986; Harmon and Hua 1991). CWD includes fallen logs, snags (dead standing trees), stumps, and large branches (Harmon et al. 1986). Snags refer to CWD which inclination is not more than $45^{\circ}$, base diameter $\geq 10 \mathrm{~cm}$, and length $>1 \mathrm{~m}$. Stumps with a height $<1 \mathrm{~m}$ were defined as CWD, which includes coarse roots above the soil surface (Harmon and Sexton 1996; Currie and Nadelhoffer 2002). Among these, dead coarse roots of fallen logs and snags were measured and recorded, and of which stumps were neglected due to they were rarely observed. Additionally, we reclassified foliar litter, dead twig, dead fine bark, and epiphytes as NWD. Three plots of $10 \mathrm{~m} \times 20 \mathrm{~m}$ of each successional forest were established for CWD and FWD investigation, and nine subplots of $1 \mathrm{~m} \times 1 \mathrm{~m}$ were established for NWD investigation. Five decay class (I-V) systems optimized according to Błońska et al. (2018) were used to classify the decomposition degree of WD based on the morphology and hardness observed in the field (Table A2). Five diameter sizes (D1-D5) were applied to classify the WD diameter according to Harmon et al. (1986) and Xiong et al. (2016), that is, $2 \mathrm{~cm} \leq \mathrm{d}<5 \mathrm{~cm}$ (D1), $5 \mathrm{~cm} \leq$ $\mathrm{d}<10 \mathrm{~cm} \quad$ (D2), $10 \mathrm{~cm} \leq \mathrm{d}<20 \mathrm{~cm}$ (D3), $20 \mathrm{~cm} \leq \mathrm{d}<40$ $\mathrm{cm}$ (D4) and $\mathrm{d} \geq 40 \mathrm{~cm}$ (D5). Then, the decay class, base 
diameter, end diameter, and length (fallen logs and large branches) or height (snags and stumps) of the WD were recorded and measured. For CWD, the length beyond the plot, only the part within the plot be recorded. Next, for the CWD with decay classes I to III, three dish samples of each decay class with a thickness of approximately $5 \mathrm{~cm}$ were obtained by chain saw. For the CWD with decay classes IV and V and FWD, three samples with a weight of approximately $500 \mathrm{~g}$ were harvested. For NWD, all samples within the subplot of $1 \mathrm{~m} \times 1$ $\mathrm{m}$ were harvested. The samples were taken back to the laboratory for stock and $\mathrm{C}$ concentration measurements.

\section{Measurement of plant debris stock and C stock}

After the dish samples of CWD from decay classes I to III were delivered to the laboratory, their diameter $\left(d_{1}\right)$ and thickness $(h)$ were measured. Then, the volume $\left(V_{1}\right)$ and density $(\rho)$ were calculated (Bonan 2008). After the CWD samples from decay classes IV and V and the FWD samples were delivered to the laboratory, we used the drainage method to determine the volume $\left(V_{2}\right)$ (Jonsson 2000). Then, we weighed these samples after oven drying at $85^{\circ} \mathrm{C}$ to a constant weight $\left(m_{1}\right)$. For NWD, the sample was weighed after oven drying at $85^{\circ} \mathrm{C}$ to a constant weight $\left(m_{2}\right)$. The volume $(V)$ of WD in the field was calculated according to Zhu et al. (2017), and the stock $(\mathrm{G})$ of WD in the field was converted by the volume $(V)$ and the sample density $(\rho)$. For $C$ concentration, the most important factor determining $\mathrm{C}$ concentration (\%) of plant debris were decay class and geographical location, and there was little difference between plant species or other factors (Zhu et al. 2017). So, for WD from the different decay classes, carbon concentrations of $50.5 \%, 50.0 \%, 49.7 \%, 43.3 \%$, and $37.9 \%$ refer to Chang et al. (2015), who have investigated the changes in the $C$ concentrations with WD decay classes in a similar subalpine forest; for NWD, a carbon concentration of 41.9\% refer to Zhu et al. (2017).

The WD density $\left(\rho, \mathrm{g} \cdot \mathrm{cm}^{-3}\right)$ was calculated as follows:

$$
\begin{aligned}
& V_{1}=\frac{\pi \times h \times d_{1}^{2}}{4} \\
& \rho=\frac{m_{1}}{V_{1 / 2}}
\end{aligned}
$$

where $m_{1}$ is the dry weight of the CWD and FWD samples (g), and $d_{1}$ and $h$ are the fresh dish sample diameter and thickness $(\mathrm{cm})$, respectively.

The volume of WD $\left(V, \mathrm{~cm}^{3}\right)$ in the field was calculated as follows:

$$
\begin{aligned}
V= & \frac{\pi \times l \times d_{2}{ }^{2}}{12}+\frac{\pi \times l \times d_{2} \times d_{3}}{12} \\
& +\frac{\pi \times l \times d_{3}{ }^{2}}{12}
\end{aligned}
$$

where $d_{2}, d_{3}$, and $l$ are the base diameter, end diameter, and length or height of the WD in the field $(\mathrm{cm})$, respectively.

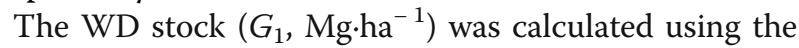
following formula:

$$
G_{1}=\frac{\sum V \times \rho}{200 \times \cos \theta \times 100}
$$

where $\theta$ is the slope of each plot $\left(^{\circ}\right), 200$ is the area of each plot $\left(\mathrm{m}^{2}\right)$, and 100 is the unit conversion factor.

The NWD stock $\left(G_{2}\right)$ was calculated using the following formula:

$$
G_{2}=\frac{\sum m_{2}}{1 \times \cos \theta \times 100}
$$

where $m_{2}$ is the dry weight of the NWD sample (g), $\theta$ is the slope of each subplot $\left(^{\circ}\right), 1$ is the area of each subplot $\left(\mathrm{m}^{2}\right)$, and 100 is the unit conversion factor.

The carbon stocks (Mg.ha ${ }^{-1}$ of C) of WD and NWD were calculated using the following formula:

$$
\text { Carbon stock }=G_{1 / 2} \times \text { carbon concentration }
$$

where $G_{1}$ and $G_{2}$ are the stocks of WD and NWD, respectively.

\section{Statistical analysis}

One-way analysis of variance (ANOVA) and least significant difference (LSD) tests were applied to examine the different significance of WD stocks and C stocks among different decay classes, among different diameter sizes, and among these successional forests. The significance was selected at the 0.05 level. The interaction effects of successional stages, decay classes, and diameter sizes on the WD stock and $\mathrm{C}$ stock were analyzed by Multivariate analysis of variance (MANOVA). All statistical analyses were carried out by IBM SPSS Statistics v. 20 (IBM Corporation, New York, USA).

\section{Results}

\section{Plant debris stock across the successional series}

Plant debris stock ranged from 25.19 to $82.89 \mathrm{Mg} \cdot \mathrm{ha}^{-1}$ across the subalpine forest successional series, and the highest and lowest stocks of plant debris were observed in the later successional stage (S5) and earlier forest stage (S1), respectively (Table 1 ). When all plant debris components were considered together, the stocks of plant debris represented a total tendency of increasing from the S1 to S6 stands except for the sudden decrease observed in S4 medium-aged earlier coniferous forest 
Table 1 The stocks and ratios of plant debris across a successional gradient in the subalpine forest on eastern Qinghai-Tibet Plateau

\begin{tabular}{lllllll}
\hline Successional series & S1 & S2 & S3 & S4 & S5 & S6 \\
\hline WD $\left(\mathrm{Mg}^{-1} \mathrm{ha}^{-1}\right)$ & $31.73 \mathrm{c}$ & $24.49 \mathrm{c}$ & $51.49 \mathrm{bc}$ & $36.07 \mathrm{c}$ & $82.46 \mathrm{a}$ & $77.27 \mathrm{ab}$ \\
NWD $\left(\mathrm{Mg}_{\mathrm{ha}}{ }^{-1}\right)$ & $1.31 \mathrm{a}$ & $0.70 \mathrm{bc}$ & $0.82 \mathrm{bc}$ & $1.07 \mathrm{ab}$ & $0.43 \mathrm{c}$ & $0.80 \mathrm{bc}$ \\
Plant debris $\left({\left.\mathrm{Mg} \cdot \mathrm{ha}^{-1}\right)}^{3}\right.$ & $33.04 \mathrm{c}$ & $25.19 \mathrm{c}$ & $52.31 \mathrm{bc}$ & $37.14 \mathrm{c}$ & $82.89 \mathrm{a}$ & $78.08 \mathrm{ab}$ \\
CWD/FWD & 39.75 & 10.57 & 79.02 & 32.33 & 84.55 & 435.63 \\
WD/NWD & 26.58 & 37.98 & 65.15 & 34.93 & 208.89 & 110.69
\end{tabular}

Stock is shown as means $(n=3)$. One-way ANOVA tests were applied among six successional series in WD, NWD, Plant debris, CWD/FWD and WD/NWD. Values followed by different lowercase letters mean significant difference among six successional series at $P=0.05$ level. WD Woody debris, NWD Non-woody debris, CWD Coarse woody debris, FWD Fine woody debris

\section{a}

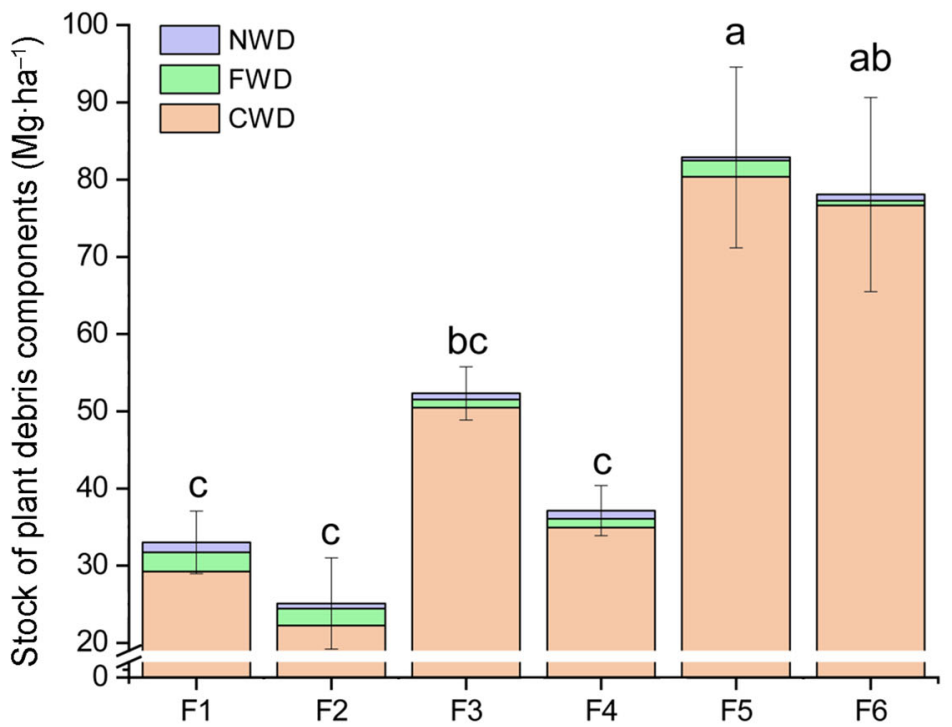

b

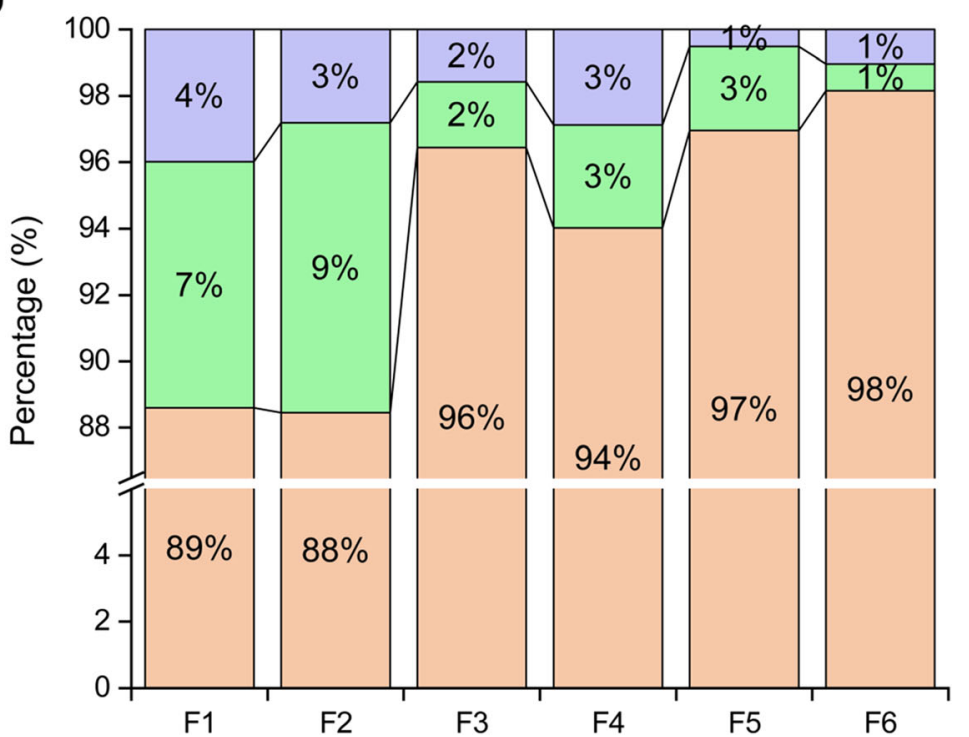

Fig. 1 Stock of plant debris component (a) and their allocation (b) in six plant communities among different stages of succession in a subalpine forest in Wanglang National Nature Reserve on eastern Qinghai-Tibet Plateau. Different lowercase letters indicate that the total stock of plant debris differed significantly among successional gradient $(P<0.05)$. Horizontal bars indicate standard errors of means $(n=3)$ 
$(F=6.34, P<0.01$; Fig. 1a). The stock was significantly higher in CWD than in FWD and NWD from all six successional stages (Fig. 1b). The proportion of CWD stock ranged from $88 \%$ to $98 \%$ along the forest succession gradient. Among these, only $1 \%-9 \%$ and $1 \%-4 \%$ of the stocks were stored in FWD and NWD, respectively (Fig. 1b). In detail, the stocks of different plant debris components were $22.20-80.37 \mathrm{Mg} \cdot \mathrm{ha}^{-1}$ for CWD, 0.63-

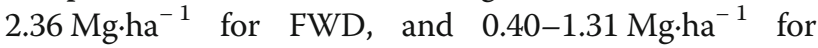
NWD (Fig. 2). CWD displayed a similar trend as that of plant debris (Fig. 1a), and the stock of CWD was significantly higher in S5 and S6 than in the S1, S2, and S4 successional stages $(F=6.28, P<0.01$; Fig. $2 \mathrm{a})$. In contrast, the stocks of FWD and NWD decreased from S1 to S6, and the NWD stock was significantly lower in S5 than in $\mathrm{S} 1(F=5.23, P<0.01$; Fig. 2c). However, slight differences in FWD stocks were observed across the forest successional series $(F=0.61, P>0.05$; Fig. $2 b)$.

The ratios of WD to NWD stocks ranged from 26.58 to 208.89, and the highest and lowest ratios of WD to NWD stocks were observed in the mid-coniferous forest (S5) and shrub forest stages (S1), respectively (Table 1).
In particular, the ratios of CWD to FWD stocks varied greatly with successional stages, ranging from 10.57 in the broadleaved forest (S2) to 435.63 in the natural coniferous forest (Table 1). Furthermore, the coefficient of variation $(\mathrm{CV})$ of plant debris stocks along the forest successional series reached $48.93 \%$ (Fig. 2d). Meanwhile, the CV of the FWD stocks was significantly higher than the CV of the NWD stocks $(P<0.05$; Fig. $2 \mathrm{~d})$.

\section{Changes in WD stocks with decay class across the successional series}

As shown in Table 2, the highest and lowest stocks of WD were observed in decay class IV $\left(13.67 \mathrm{Mg} \cdot \mathrm{ha}^{-1}\right)$ and decay class II (8.77 Mg.ha $\left.{ }^{-1}\right)$, respectively. However, a slight variation pattern of WD stock was observed across the five decay classes $(F=0.542, P>0.05$; Table 3$)$. A higher proportion of WD stock was observed in higher decay classes in the later succession stage S6, although there was no significant difference (Fig. 3). Actually, among the different successional forests, a significant difference between decay classes was observed only in the earlier succession stage (S1) but was
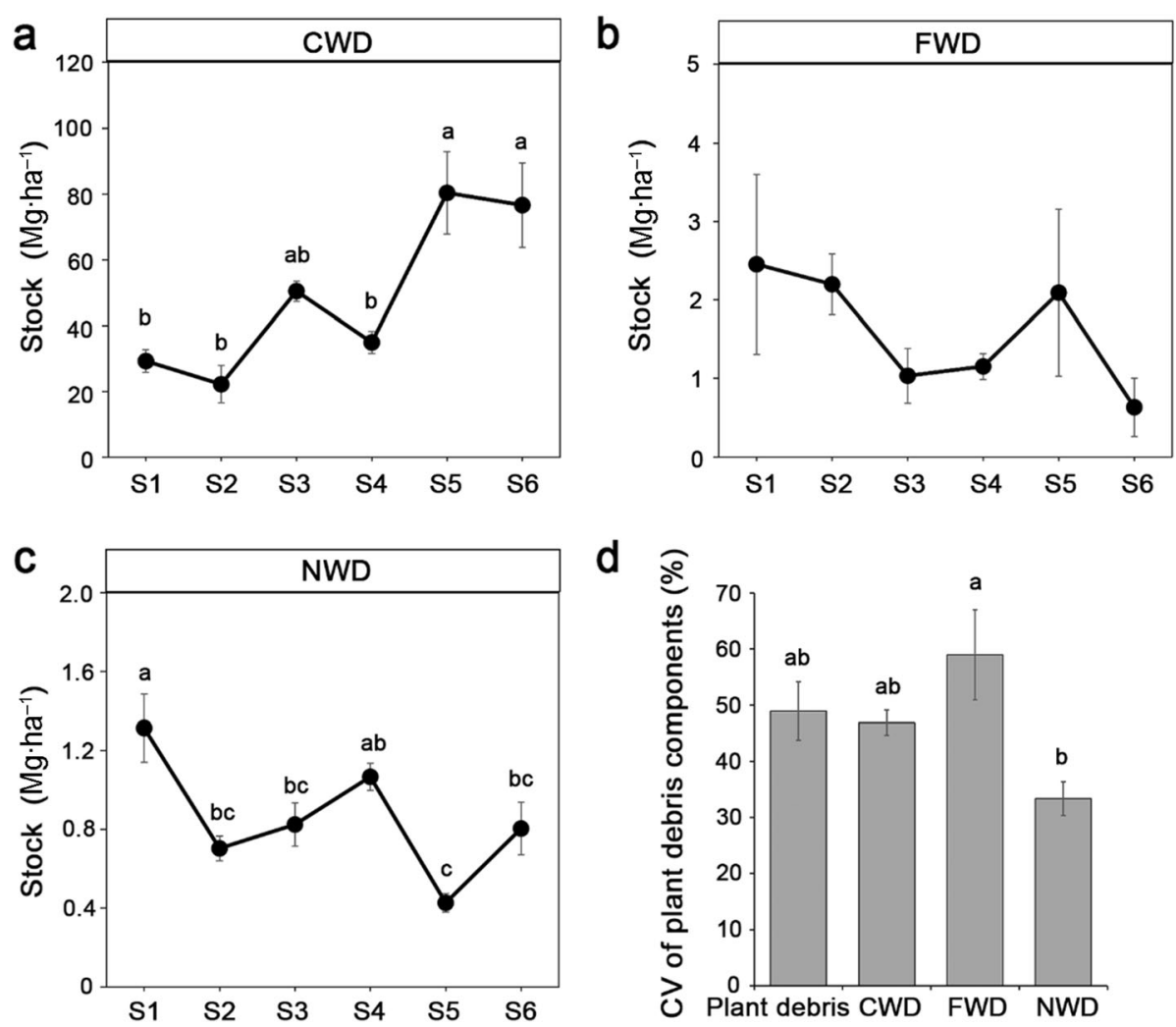

Fig. 2 Stock of coarse woody debris CWD (a), fine woody debris FWD (b) and non-woody debris NWD (c) in six plant communities among different stages of succession in a subalpine forest in Wanglang National Nature Reserve on eastern Qinghai-Tibet Plateau. Figure $\mathbf{d}$ indicates the coefficients of variation (CV) of stock of plant debris, CWD, FWD and NWD at different succession ages. Different lowercase letters mean significant difference among different succession stages or different plant debris components $(P<0.05)$. Horizontal bars indicate standard errors of means $(n=3)$ 
Table 2 Changes in woody debris stock with decay classes and diameter sizes in the subalpine forest on eastern Qinghai-Tibet Plateau

\begin{tabular}{llll}
\hline Decay classes & Stock $\left.\mathbf{( M g} \cdot \mathbf{h a}^{\mathbf{- 1}}\right)$ & Diameter sizes & Stock $\left.\mathbf{( M g} \cdot \mathbf{h a}{ }^{-\mathbf{1}}\right)$ \\
\hline I & $11.66 a$ & D1 & $0.57 \mathrm{c}$ \\
II & $8.77 \mathrm{a}$ & D2 & $1.59 \mathrm{c}$ \\
III & $13.56 \mathrm{a}$ & D3 & $12.95 \mathrm{~b}$ \\
IV & $13.67 \mathrm{a}$ & D4 & $13.24 \mathrm{~b}$ \\
V & $11.39 \mathrm{a}$ & D5 & $35.38 \mathrm{a}$ \\
\hline
\end{tabular}

Stock is shown as means ( $n=3$ ). One-way ANOVA tests were applied among five decay classes and five diameter sizes. Values followed by different lowercase letters mean significant difference among five decay classes or five diameter sizes at $P=0.05$ level. D1-D5 indicated woody debris in diameter of $2 \mathrm{~cm} \leq \mathrm{d}<5 \mathrm{~cm}, 5 \mathrm{~cm} \leq \mathrm{d}<10 \mathrm{~cm}, 10 \mathrm{~cm} \leq \mathrm{d}<20 \mathrm{~cm}, 20 \mathrm{~cm} \leq \mathrm{d}<40 \mathrm{~cm}$, $\mathrm{d} \geq 40 \mathrm{~cm}$, respectively

not observed in the other forests (Fig. 3). Similarly, the WD stock of each decay class varied slightly among the six plant communities (Fig. 3).

\section{Changes in WD stocks with diameter size across the successional series}

The WD stock was significantly higher in largerdiameter (D5) than finer-diameter WD (D1 and D2) $(F=25.97, P<0.001$; Tables 2 and 3). Consistently, the stock of the coarsest diameter (D5) was remarkably higher than that of the other diameter sizes in the older successional series S5 and S6, and presented a significant increasing tendency with diameter size $(P<0.05)$. The highest stock at S3 and S4 stages were observed in the coarser diameters of D4 and D3, respectively $(P<0.05)$. The stocks of diameters D3 and D5 were higher than that of the finer WD in S1. However, a slight difference in WD stock was observed between diameter sizes at the S2 stage $(P>0.05$; Fig. 4$)$. Meanwhile, the WD stock of D3, D4, and D5 diameters varied significantly with successional stages (Fig. 4). Furthermore, the WD stock of diameter D5 at S5 or S6 stage was obviously higher than this of the earlier succession stands $(P<0.05)$, and the highest WD stocks of diameters D4 and D3 were observed in the mid-successional forests S3 and S4, respectively $(P<0.05$; Fig. 4). Additionally, an interaction effect was observed among successional series, decay classes, and diameter classes for the stock measured in the WD ( $F=3.576, P<0.001$; Table 3$)$, although the WD stock was not significantly affected by decay class $(F=$ $0.542, P>0.05)$.

\section{The $\mathrm{C}$ stocks of plant debris across the successional series} The plant debris $C$ stocks ranged from 10.30 to 38.87 $\mathrm{Mg} \cdot \mathrm{ha}^{-1}$ across the subalpine forest succession series, and the highest and lowest stocks of plant debris were observed in the later succession stage (S5) and the earlier forest stage (S2), respectively (Table 4), showing a global tendency of increasing from the S1 to S6 stands except for the sudden decrease observed in S4 mediumaged earlier coniferous forest (Fig. 5a). Furthermore, the stock was significantly higher in CWD than in FWD and NWD at each successional stage (Fig. 5). Compared with the mean proportions of C stocks of NWD (2\%) and FWD (4.5\%), the minimum proportion of CWD C storage is $87 \%$ in the subalpine forest ecosystem (Fig. 5b). Especially in the later stages of succession, the total plant debris $C$ pool was dominated mainly by CWD $(P<0.001$; Fig. 5b).

Among plant debris components, the changes in the plant debris $\mathrm{C}$ stock with plant debris component and successional stages showed a similar pattern of plant debris component stock (Fig. 2). The C stock of CWD

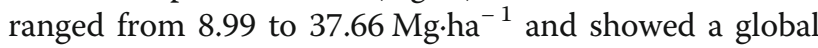
increase trend (Fig. 6a), which was significantly higher in the later successional stages S5 and S6 than in the earlier successional stages S1 and S2 $(P<0.05$; Fig. 6a). Most importantly, the $\mathrm{C}$ stored in CWD was more than four times higher in the highest forest (S5) than in the lowest forest (S2) (Fig. 6a). The $\mathrm{C}$ stock ranged from 0.30 to $1.17 \mathrm{Mg}^{-h^{-1}}$ for FWD (Fig. 6b) and 0.18 to 0.55

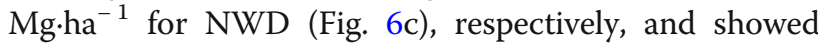
the opposite tendency to CWD. C stored in FWD and NWD $(P<0.05)$ was lower in the S6 stage than in the S1 stage, but this difference was nonsignificant for FWD $(P>0.05$; Figs. $6 \mathrm{~b}$ and $\mathrm{c}$ ). Besides, the CVs of the $\mathrm{C}$ stocks varied significantly with the different components of plant debris. The CV of the FWD C stock was significantly higher than the CV of the CWD and NWD stocks in the six successional stages $(P<0.05$; Fig. $6 \mathrm{~d})$.

Table 3 Multivariate analysis of variance (MANOVA) for the effects of succession series, decay classes and diameter sizes on the stocks of woody debris and carbon

\begin{tabular}{|c|c|c|c|c|c|}
\hline \multirow[t]{2}{*}{ Source variance } & \multirow[t]{2}{*}{$d f$} & \multicolumn{2}{|c|}{ Stock of woody debris } & \multicolumn{2}{|c|}{ C stock of woody debris } \\
\hline & & $F$-value & $P$-value & $F$-value & $P$-value \\
\hline Succession series (S) & 5 & 5.377 & $<0.001^{* * *}$ & 7.149 & $<0.001^{* * *}$ \\
\hline Decay classes (DC) & 4 & 0.542 & 0.705 & 1.564 & 0.185 \\
\hline Diameter sizes (D) & 4 & 25.973 & $<0.001^{* * *}$ & 27.185 & $<0.001^{* * *}$ \\
\hline$S \times D C \times D$ & 5 & 3.576 & $<0.001^{* * *}$ & 4.072 & $<0.001^{* * *}$ \\
\hline
\end{tabular}

Significant effect: ${ }^{* * *} P<0.001$ 


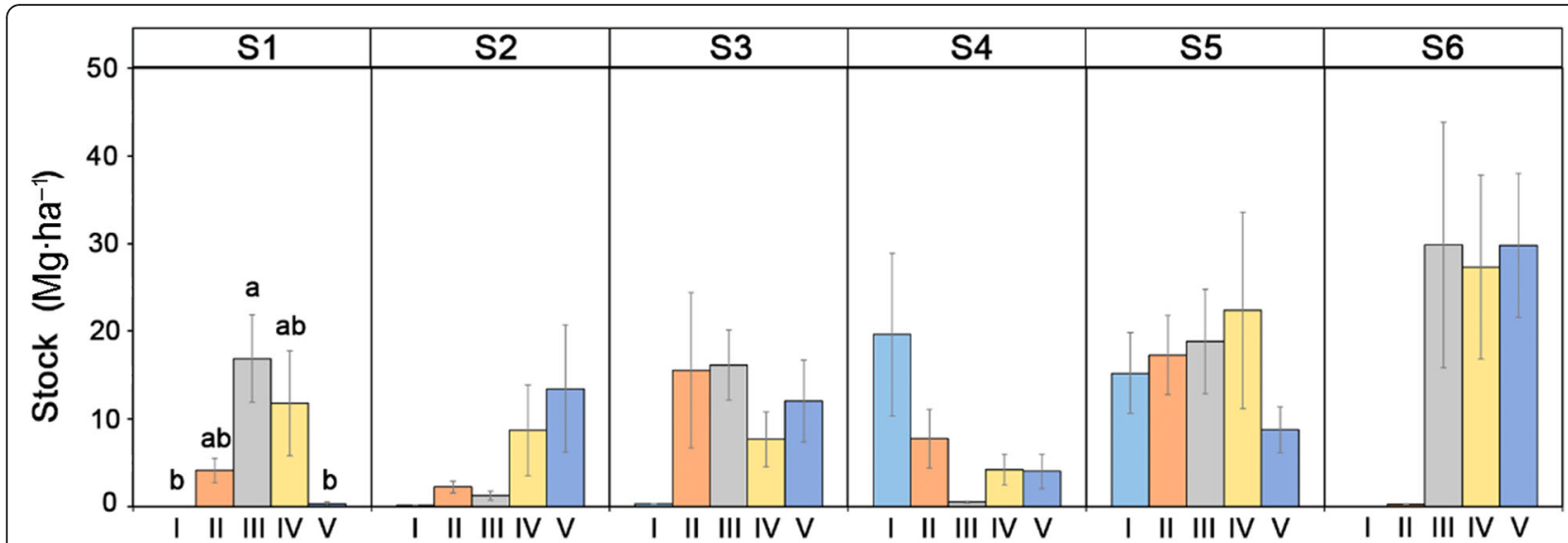

Fig. 3 Stock of woody debris in different decay classes among different stages of succession in a subalpine forest in Wanglang National Nature Reserve on eastern Qinghai-Tibet Plateau. Different lowercase letters mean significant difference among different decay classes $(P<0.05)$.

Horizontal bars indicate standard errors of means $(n=3)$

Both succession stage $(F=7.147, P<0.001)$ and diameter class $(F=27.185, P<0.001)$ had significant effects on the $\mathrm{C}$ concentration of WD, but decay class had a slight effect on the $\mathrm{C}$ stock $(F=1.564, P>0.05)$. Furthermore, the $C$ stock of WD was significantly influenced by the interaction among succession age, diameter size, and decay class $(F=4.072, P<0.001$; Table 3$)$.

\section{Discussion}

Our results indicated that plant debris stocks increased from the earlier successional stage to the later successional stage except for decreasing at the S4 successional stage in the subalpine forest region, which partly supported our first hypothesis. Meanwhile, the results showed that the WD stock varied slightly at different decay classes but significantly at different diameter sizes among the six plant communities, which was partly consistent with our second hypothesis. Additionally, our results still demonstrated a global tendency of increase from the S1 to S6 stands except for the decrease observed in S4 mediumaged earlier coniferous forest, which partly agreed with the third hypothesis. This result confirmed that CWD changed greatly with forest succession and demonstrated that CWD dominated the plant debris in natural forests and that the ratios and components of plant debris fluctuated sharply with forest successional series.

\section{Changes in WD and NWD stocks with forest succession}

Forest succession is an important factor that affects the stocks of CWD or litter in different forest ecosystems

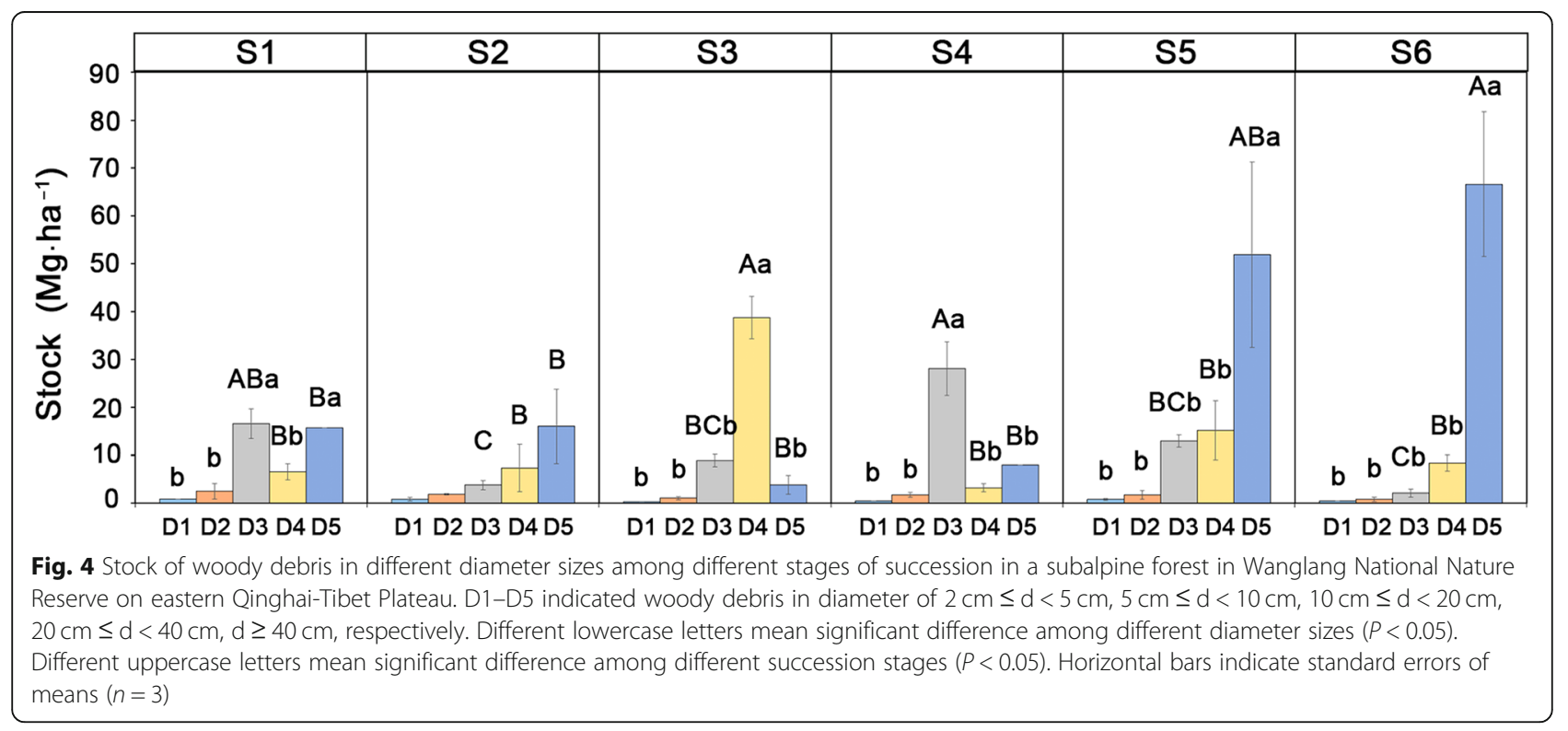


Table 4 The carbon stock of plant debris across a successional gradient in the subalpine forest on eastern Qinghai-Tibet Plateau

\begin{tabular}{lllllll}
\hline Successional series & S1 & S2 & S3 & S4 & S5 & S6 \\
\hline WD $\left(\mathrm{Mg} \cdot h a^{-1}\right)$ & $14.97 \mathrm{c}$ & $10.00 \mathrm{c}$ & $23.73 \mathrm{bc}$ & $17.37 \mathrm{c}$ & $38.69 \mathrm{a}$ & $33.14 \mathrm{ab}$ \\
NWD $\left(\mathrm{Mg} \cdot \mathrm{ha}^{-1}\right)$ & $0.55 \mathrm{a}$ & $0.29 \mathrm{bc}$ & $0.35 \mathrm{bc}$ & $0.45 \mathrm{ab}$ & $0.18 \mathrm{c}$ & $0.34 \mathrm{bc}$ \\
Plant debris $\left({\left.\mathrm{Mg} \cdot h \mathrm{ha}^{-1}\right)}^{15.53 \mathrm{c}}\right.$ & $10.30 \mathrm{c}$ & $24.07 \mathrm{bc}$ & $17.82 \mathrm{c}$ & $38.87 \mathrm{a}$ & $33.48 \mathrm{ab}$
\end{tabular}

Carbon stock is shown as means $(n=3)$. One-way ANOVA tests were applied six successional series in WD, NWD, and Plant debris. Values followed by different lowercase letters mean significant difference among six successional series at $P=0.05$ level. WD Woody debris, NWD Non-woody debris, $C$ Carbon

(Idol et al. 2001; Sefidi 2010; Zhang et al. 2011; Aryal et al. 2015). However, the tendency of the plant debris biomass and C stocks, particularly in CWD components, differed greatly from those in previous reports (Table 5).
A greater amount of CWD was found in earlier- or older-growth forests than in other stands (presenting a 'U-shaped' pattern) (Eaton and Lawrence 2006; Sefidi 2010). A monotonic increase in CWD amount or C
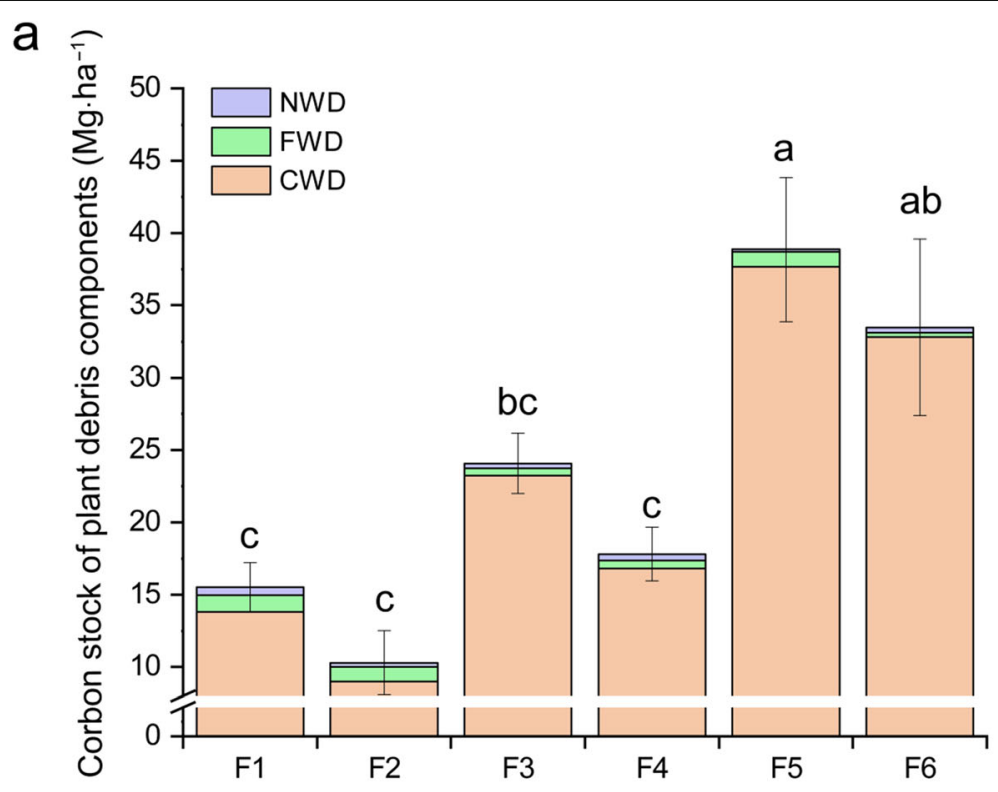

b

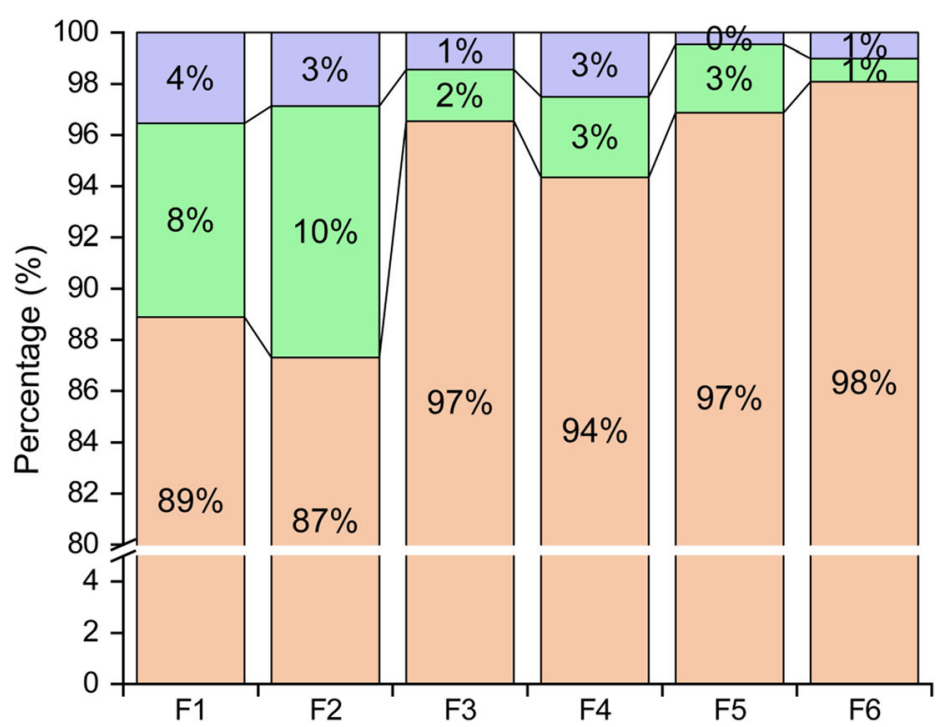

Fig. 5 Carbon stock of plant debris component (a) and their allocation (b) in six plant communities among different stages of succession in a subalpine forest in Wanglang National Nature Reserve on eastern Qinghai-Tibet Plateau. Different lowercase letters indicate that the total carbon stock of plant debris differed significantly among successional gradient $(P<0.05)$. Horizontal bars indicate standard errors of means $(n=3)$ 

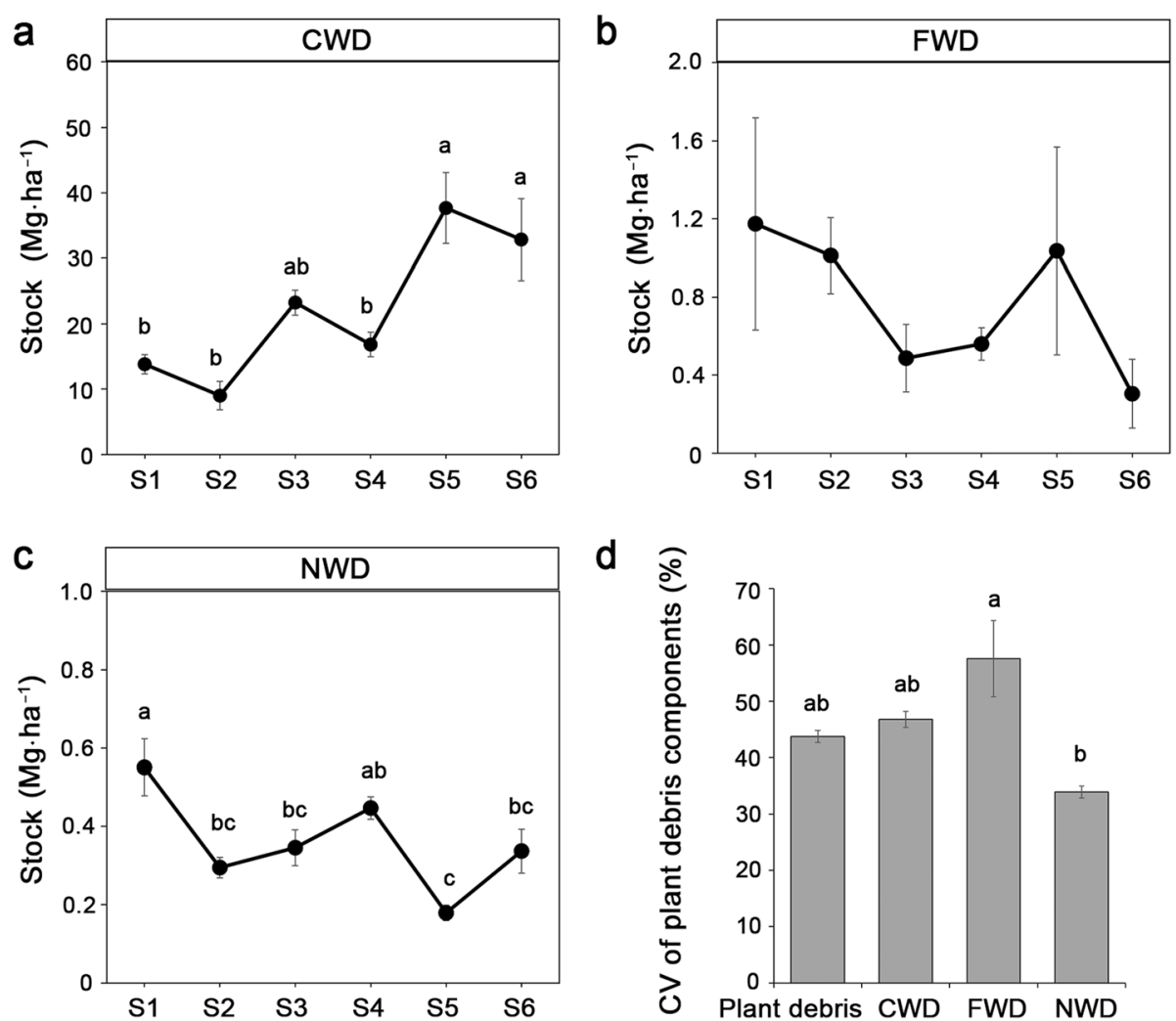

Fig. 6 Carbon stock of coarse woody debris CWD (a), fine woody debris FWD (b) and non-woody debris NWD (c) in six plant communities among different stages of succession in a subalpine forest in Wanglang National Nature Reserve on eastern Qinghai-Tibet Plateau. Figure $\mathbf{d}$ indicates the coefficients of variation (CV) of carbon stock of plant debris, CWD, FWD and NWD at different succession ages. Different lowercase letters mean significant difference among different succession stages or different plant debris components $(P<0.05)$. Horizontal bars indicate standard errors of means $(n=3)$

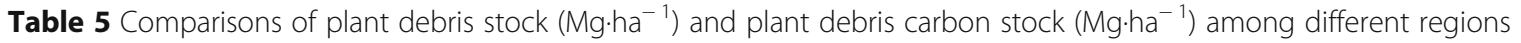

\begin{tabular}{|c|c|c|c|c|c|c|c|c|}
\hline \multirow[t]{2}{*}{ Area } & \multicolumn{2}{|c|}{ Earlier succession } & \multicolumn{2}{|c|}{ Mid-succession } & \multicolumn{2}{|c|}{ Later succession } & \multirow[t]{2}{*}{ Tendency } & \multirow[t]{2}{*}{ Reference } \\
\hline & CWD & Carbon & CWD & Carbon & CWD & Carbon & & \\
\hline Subalpine forests of western Sichuan & 25.73 & 11.40 & 50.45 & 23.24 & 63.98 & 29.10 & Increasing & This study \\
\hline $\begin{array}{l}\text { Primary temperate forests of southern } \\
\text { Chile }\end{array}$ & 18.00 & - & 64.50 & - & 173.75 & - & Increasing & Carmona et al. (2002) \\
\hline Gorazbon forests of Northern Iran & $\begin{array}{l}37.05 \\
\left(\mathrm{~m}^{3} \cdot h \mathrm{a}^{-1}\right)\end{array}$ & - & $\begin{array}{l}25.95 \\
\left(m^{3} \cdot h a^{-1}\right)\end{array}$ & - & $\begin{array}{l}51.25 \\
\left(m^{3} \cdot h a^{-1}\right)\end{array}$ & - & 'U-shaped' & Sefidi (2010) \\
\hline Dry tropical forest of Southern Mexico & 51.62 & - & 11.38 & - & 37.46 & - & 'U-shaped' & $\begin{array}{l}\text { Eaton and Lawrence } \\
\text { (2006) }\end{array}$ \\
\hline \multirow{2}{*}{$\begin{array}{l}\text { Upland oak-hickory forests of southern } \\
\text { Indiana }\end{array}$} & 137.2 & 69.0 & 39.8 & 19.9 & 59.0 & 29.7 & Decreasing & Idol et al. (2001) \\
\hline & NWD & Carbon & NWD & Carbon & NWD & Carbon & & \\
\hline Subalpine forests of western Sichuan & 1.01 & 0.42 & 0.82 & 0.35 & 0.77 & 0.32 & Decreasing & This study \\
\hline $\begin{array}{l}\text { Semi-evergreen tropical forests of } \\
\text { south-eastern Mexico }\end{array}$ & 5.20 & 2.34 & 7.10 & 3.20 & 6.29 & 2.83 & $\begin{array}{l}\text { Increasing than } \\
\text { decreasing }\end{array}$ & Aryal et al. (2015) \\
\hline Subtropical forests of eastern China & 6.38 & $\begin{array}{l}0.60 \\
(\%)\end{array}$ & 8.15 & $\begin{array}{l}0.65 \\
(\%)\end{array}$ & 11.69 & $\begin{array}{l}0.75 \\
(\%)\end{array}$ & Increasing & Yan et al. (2009) \\
\hline
\end{tabular}


density was found following secondary forest succession in Chiloe (Carmona et al. 2002) and Chinese forests (Tang and Zhou 2005; Zeng et al. 2015; Zhu et al. 2017). Idol et al. (2001) have shown a large decrease in volume and mass of woody debris from recently harvested to mature stands (Table 5). However, our results suggested a global increasing curve for CWD with succession except for the sudden decrease observed in the mediumaged earlier coniferous forest (S4) (Figs. 2a and 6a). In general, the accumulation of CWD depends not only on plant debris production but also on the rate of decomposition (Tritton 1981; Sturtevant et al. 1997). Since CWD breaks down persistently and slowly, its production rates ultimately outpace its decomposition rates. Therefore, the later succession stages with more aboveground biomass commonly have higher CWD stocks (Smith et al. 2006), while the earlier successional stands with less live biomass have lower CWD stocks. Most importantly, the difference is likely that their analyses were simply based on the data of general successional gradients that lacked consideration of earlier coniferous forests. Although the earlier coniferous forest has a higher succession stage than that of mixed forest, it has a rapid growth period for trunk biomass. Meanwhile, the CWD is almost decomposed in the earlier stage, and there is relatively little WD, especially CWD.

Compared with the biomass and $C$ stocks of CWD, the stocks of NWD had an opposite tendency (Figs. 2c and $6 \mathrm{c})$. First, we estimated that the biomass and $\mathrm{C}$ stocks reached a peak in the earlier succession stage (S1) and then decreased with the forest succession stage but suddenly increased in the medium stage earlier coniferous forest (S4). However, in other forest ecosystems (Table 5), the production of litter increased through the succession process (Yan et al. 2009; Zhang et al. 2013) or increased rapidly and then decreased with the forest stage (Aryal et al. 2015). The discrepancy of rates of input (aboveground biomass) and output (decomposition) may be one of the possible reasons (Dent et al. 2006; Wang et al. 2007). The tree species of litter and climate of different forest ecosystems also determined the decomposition rates of litter (Müller-Using and Bartsch 2009; Berbeco et al. 2012). Second, in contrast to the CWD stock, the higher stock in the young shrub forest (S1) was contributed by shrub twigs. Meanwhile, the later successional stage of the mid- and mature coniferous forests (S5 and S6) had lower stocks, which was likely related to the lower inputs of needles and the faster losses of thinner litter, which decelerated the amounts of remains and sped up the rate of decomposition.

\section{The effect of decay class and diameter on WD stock across the succession series}

Interestingly, decay class did not affect the storage of WD in five successional stages of forest ecosystems in our study (Fig. 3). However, it has been reported that decay class IV was the most abundant decay class in a Northern Iran forest (Sefidi 2010). Yan et al. (2007) have reported that the evergreen broadleaved forests of later successional stages have a higher proportion of WD with decay classes IV and V in the subtropical region of eastern China. In contrast, Carmona et al. (2002) have reported that CWD at advanced decay levels was more abundant in earlier-stage stands, while most CWD was in the intermediate decay classes in older forests. These contradictions can be partly attributed to the difference in the vegetation composition. Additionally, all study sites were located within a nature reserve with little disturbance and management practice, which is another crucial reason for the average distribution of WD at different decay classes.

In addition to the significant effect of the succession stage on the stock of plant debris, diameter size influenced the storage of WD (Fig. 4). Our results illustrated that larger-diameter WD dominated the plant debris as the successional stage increased. Our current estimates were also confirmed by several studies investigating whether CWD was dominant in plant debris across forest succession stage (Eaton and Lawrence 2006; Van Mantgem et al. 2009; Sefidi 2010; Yang et al. 2010; Zeng et al. 2015). Tree species at different successional stages produced different biomasses of CWD. For instance, tree species with a cohort of old and large-diameter fir and spruce coniferous species in an old-growth stand could lead to more biomass of CWD, while most were small and thin willow shrub and birch in the earlier successional forest. However, as suggested by other reports, the relative contribution of CWD to the plant debris biomass declined with forest succession (Brown and Lugo 1990; Krankina and Harmon 1995; Delaney et al. 1998). The difference may be due to different standards of classification of diameter sizes and climate conditions used at different study sites.

\section{Plant debris carbon stock across the succession series}

Countrywide, the estimated plant debris $C$ stock was $5.88 \pm 0.35 \mathrm{Mg} \mathrm{C} \cdot \mathrm{ha}^{-1}$ in a temperate forest (Zhu et al. 2017). In our study, the plant debris $C$ stock ranged

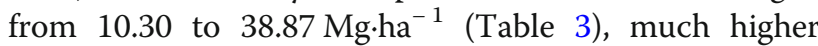
than the average of Chinese forests but similar to some results from local forests in China (Yang et al. 2010) and southern Indiana (Idol et al. 2001) (Table 5). The higher $\mathrm{C}$ stock in our ecosystem is likely a result of natural forests with little disturbance and management practices. The source of nationwide data, including many young- 
growth plantations and areas of excessive harvest, occurred in planted forests (Guo et al. 2013) and resulted in a low average $C$ stock value. In addition, the plant debris investigation in our study tended to select forests with a greater distribution of WD (Pan et al. 2011), which caused the overestimates of plant debris amount and $\mathrm{C}$ stock.

\section{Conclusions}

The change in the biomass and C stock of WD represented a total tendency of increasing from the S1 to S6 stands, while the changes of FWD and NWD were decreased across the subalpine forest succession series. CWD dominated the plant debris regardless of the forest successional stages. A larger diameter size and advanced decay class tended to be abundant in the older stage of succession. Furthermore, the $\mathrm{C}$ stored in CWD in later successional forests was four times higher than in earlier successional forests. Together, the stock and role of WD, particularly CWD, varied greatly with the forest successional stage and dominated the $\mathrm{C}$ cycle in the subalpine forest ecosystem. The results suggested keeping CWD on the forest floor be a critical strategy for maintaining forest productivity and implementing sustainable forest management in the subalpine forest on the eastern Qinghai-Tibet Plateau. Additionally, CWD plays an important role in the global $\mathrm{C}$ cycle in subalpine forest ecosystems.

\section{Supplementary Information}

The online version contains supplementary material available at https://doi. org/10.1186/s40663-021-00320-0.

Additional file 1: Fig. A1. Distribution of the study sites across a subalpine forest succession gradient in Wanglang National Nature Reserve on eastern Qinghai-Tibet Plateau. Figures b and c indicate the location of study region in China and Pingwu county, Figure a indicates the distribution of study sites at Wanglang National Nature Reserve. S1: Shrub forest; S2: Broad-leaved forest; S3: Mixed forest; S4: Early coniferous forest; S5: Mid-coniferous forest and S6: Nature coniferous forest. Table A1. Site characteristics across a successional gradient in the subalpine forest on eastern Qinghai-Tibet Plateau. Table A2. Decay classes of woody debris.

\section{Acknowledgements}

The authors of this study would like to thank all people of Wanglang National Nature Reserve involved in the initial sampling assignments.

\section{Authors' contributions}

WQY and ZHW convinced conceptualization. ZHW analyzed data. ZHW led the writing of the manuscript. WQY led the review and editing of the manuscript. All authors made contributions to data collection via fieldwork or lab work. All authors read and approved the final manuscript.

\section{Funding}

This work was financially supported by the National Nature Science Foundation of China $(32071554,31570445)$.
Availability of data and materials

All data generated or analyzed during this study are included in this published article.

\section{Declarations}

Ethics approval and consent to participate

Not applicable.

\section{Consent for publication}

Not applicable.

\section{Competing interests}

The authors declare that they have no competing interests.

\section{Author details}

${ }^{1}$ School of Life Sciences, Taizhou University, Taizhou 318000, China. ${ }^{2}$ Wanglang National Nature Reserve Authority, Pingwu 622550, Sichuan, China.

Received: 3 January 2021 Accepted: 3 June 2021

Published online: 08 July 2021

\section{References}

Aryal DR, De Jong BH, Ochoa-Gaona S, Mendoza-Vega J, Esparza-Olguin L (2015) Successional and seasonal variation in litterfall and associated nutrient transfer in semi-evergreen tropical forests of SE Mexico. Nutrient Cycl Agroecosyst 103(1):45-60. https://doi.org/10.1007/s10705-015-9719-0

Berbeco MR, Melillo JM, Orians CM (2012) Soil warming accelerates decomposition of fine woody debris. Plant Soil 356(1-2):405-417. https://doi. org/10.1007/s11104-012-1130-x

Błońska E, Kacprzyk M, Spolnik A (2017) Effect of deadwood of different tree species in various stages of decomposition on biochemical soil properties and carbon storage. Ecol Res 32(2):193-203. https://doi.org/10.1007/s11284016-1430-3

Błońska E, Klamerus-Iwan A, Łagan S, Lasota J (2018) Changes to the water repellency and storage of different species of deadwood based on decomposition rate in a temperate climate. Ecohydrology 11(8):e2023. https://doi.org/10.1002/eco.2023

Bonan GB (2008) Forests and climate change: forcings, feedbacks, and the climate benefits of forests. Science 320(5882):1444-1449. https://doi.org/1 $0.1126 /$ science 1155121

Brassard BW, Chen HY (2008) Effects of forest type and disturbance on diversity of coarse woody debris in boreal forest. Ecosystems 11(7):1078-1090. https:// doi.org/10.1007/s10021-008-9180-x

Brown S, Lugo AE (1990) Tropical secondary forests. J Trop Ecol 6(1):1-32. https:// doi.org/10.1017/S0266467400003989

Carmona MR, Armesto JJ, Aravena JC, Pérez CA (2002) Coarse woody debris biomass in successional and primary temperate forests in Chiloé Island, Chile. Forest Ecol Manag 164(1-3):265-275. https://doi.org/10.1016/S0378-1127(01 )00602-8

Chang CH, Wu FZ, Wang Z, Tan B, Cao R, Yang WQ, Cornelissen JH (2019) Effects of Epixylic Vegetation Removal on the Dynamics of the Microbial Community Composition in Decaying Logs in an Alpine Forest. Ecosystems 22(7):1478-1496. https://doi.org/10.1007/s10021-019-00351-3

Chang CH, Wu FZ, Yang WQ, Tan B, Xiao S, Li J, Gou XL (2015) Changes in log quality at different decay stages in an alpine forest. Chin J Plant Ecol 39(1): 14-22 (in Chinese). https://doi.org/10.17521/cjpe.2015.0002

Cornwell WK, Cornelissen JH, Allison SD, Bauhus J, Eggleton P, Preston CM, Scarff F, Weedon JT, Wirth C, Zanne AE (2009) Plant traits and wood fates across the globe: rotted, burned, or consumed? Glob Chang Biol 15(10):2431-2449. https://doi.org/10.1111/j.1365-2486.2009.01916.x

Currie WS, Nadelhoffer KJ (2002) The imprint of land-use history: patterns of carbon and nitrogen in downed woody debris at the Harvard Forest. Ecosystems 5(5):446-460. https://doi.org/10.1007/s10021-002-1153-x

Delaney M, Brown S, Lugo AE, Torres-Lezama A, Quintero NB (1998) The quantity and turnover of dead wood in permanent forest plots in six life zones of Venezuela 1. Biotropica 30(1):2-11. https://doi.org/10.1111/j.1744-7429.1998, tb00364.x

Dent DH, Bagchi R, Robinson D, Majalap-Lee N, Burslem DF (2006) Nutrient fluxes via litterfall and leaf litter decomposition vary across a gradient of soil 
nutrient supply in a lowland tropical rain forest. Plant Soil 288(1-2):197-215 https://doi.org/10.1007/s11104-006-9108-1

Eaton JM, Lawrence D (2006) Woody debris stocks and fluxes during succession in a dry tropical forest. Forest Ecol Manag 232(1-3):46-55. https://doi.org/10.1 016/j.foreco.2006.05.038

Guo Z, Hu H, Li P, Li N, Fang J (2013) Spatio-temporal changes in biomass carbon sinks in China's forests from 1977 to 2008. Sci China Life Sci 56(7): 661-671. https://doi.org/10.1007/s11427-013-4492-2

Guo C, Cornelissen JH, Tuo B, Ci H, Yan ER (2020) Invertebrate phenology modulates the effect of the leaf economics spectrum on litter decomposition rate across 41 subtropical woody plant species. Funct Ecol 34(3):735-746. https://doi.org/10.1111/1365-2435.13496

Hagemann U, Moroni MT, Shaw CH, Kurz WA, Makeschin F (2010) Comparing measured and modelled forest carbon stocks in high-boreal forests of harvest and natural-disturbance origin in Labrador, Canada. Ecol Model 221(5):825-839. https://doi.org/10.1016/j.ecolmodel.2009.11.024

Hall S, Burke I, Hobbs N (2006) Litter and dead wood dynamics in ponderosa pine forests across a 160-year chronosequence. Ecol Appl 16(6):2344-2355. https://doi.org/10.1890/1051-0761(2006)016[2344:LADWDI]2.0.CO;2

Harmon ME, Hua C (1991) Coarse woody debris dynamics in two old-growth ecosystems. BioScience 41(9):604-610. https://doi.org/10.2307/1311697

Harmon ME, Sexton J (1996) Guidelines for measurements of Woody detritus in Forest ecosystems. US LTER Network Office, Seattle https://digitalrepository. unm.edu/lter_reports/148. Accessed 3 Jan 2021

Harmon ME, Franklin JF, Swanson FJ, Sollins P, Gregory S, Lattin J, Anderson N, Cline S, Aumen N, Sedell J (1986) Ecology of coarse woody debris in temperate ecosystems. Adv Ecol Res 15:133-302. https://doi.org/10.1016/ S0065-2504(08)60121-X

Harmon ME, Fasth B, Woodall CW, Sexton J (2013) Carbon concentration of standing and downed woody detritus: effects of tree taxa, decay class, position, and tissue type. Forest Ecol Manag 291:259-267. https://doi.org/10.1 016/j.foreco.2012.11.046

Herrmann S, Kahl T, Bauhus J (2015) Decomposition dynamics of coarse woody debris of three important central European tree species. Forest Ecosyst 2(1): 27. https://doi.org/10.1186/s40663-015-0052-5

Idol TW, Figler RA, Pope PE, Ponder F Jr (2001) Characterization of coarse woody debris across a 100 years chronosequence of upland oak hickory forest. Forest Ecol Manag 149(1-3):153-161. https://doi.org/10.1016/S0378-112 7(00)00536-3

Iwashita DK, Litton CM, Giardina CP (2013) Coarse woody debris carbon storage across a mean annual temperature gradient in tropical montane wet forest. Forest Ecol Manag 291:336-343. https://doi.org/10.1016/j.foreco.2012.11.043

Jonsson BG (2000) Availability of coarse woody debris in a boreal old-growth Picea abies forest. J Veg Sci 11(1):51-56. https://doi.org/10.2307/3236775

Jonsson M, Fraver S, Jonsson BG (2011) Spatio-temporal variation of coarse woody debris input in woodland key habitats in Central Sweden. Silv Fenn 45(5):957967 http://www.metla.fi/silvafennica/full/sf45/sf455957. Accessed 3 Jan 2021

Krankina ON, Harmon M (1995) Dynamics of the dead wood carbon pool in northwestern Russian boreal forests. Water Air Soil Poll 82(1-2):227-238. https://doi.org/10.1007/BF01182836

Kurz W, Dymond C, White T, Stinson G, Shaw C, Rampley G, Smyth C, Simpson B, Neilson E, Trofymow J (2009) CBM-CFS3: a model of carbon-dynamics in forestry and land-use change implementing IPCC standards. Ecol Model 220(4):480-504. https://doi.org/10.1016/j.ecolmodel.2008.10.018

Lebrija-Trejos E, Meave JA, Poorter L, Pérez-García EA, Bongers F (2010) Pathways, mechanisms and predictability of vegetation change during tropical dry forest succession. Perspect Plant Ecol Evol Syst 12(4):267-275. https://doi. org/10.1016/j.ppees.2010.09.002

Li J, Pei L, Kang W, Zhao S, Yang H, Li J (2012) Study on mosses diversity in Wanglang National Nature Reserve, Sichuan Province. Acta Bot Bor-Occid Sin 32(11):2344-2351 (in Chinese)

Liu Q (2002) Ecological research on subalpine coniferous forests in China. Sichuan University Press, Chengdu (in Chinese)

Moreira AB, Gregoire TG, do Couto HT (2019) Estimation of the volume, biomass and carbon concentration of coarse woody debris within two forest types in the state of São Paulo, Brazil. For Int J Forest Res 92(3):278-286. https://doi. org/10.1093/forestry/cpz009

Müller-Using S, Bartsch N (2009) Decay dynamic of coarse and fine woody debris of a beech (Fagus sylvatica L.) forest in Central Germany. Eur J Forest Res 128(3):287-296. https://doi.org/10.1007/s10342-009-0264-8
Pan Y, Birdsey RA, Fang J, Houghton R, Kauppi PE, Kurz WA, Phillips OL, Shvidenko A, Lewis SL, Canadell JG (2011) A large and persistent carbon sink in the world's forests. Science 333(6045):988-993. https://doi.org/10.1126/ science.1201609

Prescott CE, Corrao K, Reid AM, Zukswert JM, Addo-Danso SD (2017) Changes in mass, carbon, nitrogen, and phosphorus in logs decomposing for 30 years in three Rocky Mountain coniferous forests. Can J For Res 47(10):1418-1423. https://doi.org/10.1139/cjfr-2017-0001

Puyravaud JP, Dufour C, Aravajy S (2003) Rain forest expansion mediated by successional processes in vegetation thickets in the Western Ghats of India. J Biogeogr 30(7):1067-1080. https://doi.org/10.1046/j.1365-2699.2003.00882.x

Raich JW, Russell AE, Bedoya-Arrieta R (2007) Lignin and enhanced litter turnover in tree plantations of lowland Costa Rica. Forest Ecol Manag 239(1-3):128135. https://doi.org/10.1016/j.foreco.2006.11.016

Russell MB, Fraver S, Aakala T, Gove JH, Woodall CW, D'Amato AW, Ducey MJ (2015) Quantifying carbon stores and decomposition in dead wood: a review. Forest Ecol Manag 350:107-128. https://doi.org/10.1016/j.foreco.2015. 04.033

Schilling EM, Waring BG, Schilling JS, Powers JS (2016) Forest composition modifies litter dynamics and decomposition in regenerating tropical dry forest. Oecologia 182(1):287-297. https://doi.org/10.1007/s00442-016-3662-x

Sefidi K (2010) Characteristics of coarse woody debris in successional stages of natural beech (Fagus orientalis) forests of northern Iran. J Forest Sci 56(1):717. https://doi.org/10.17221/113/2008-JFS

Shorohova E, Kapitsa E (2016) The decomposition rate of non-stem components of coarse woody debris (CWD) in European boreal forests mainly depends on site moisture and tree species. Eur J Forest Res 135(3):593-606. https:// doi.org/10.1007/s10342-016-0957-8

Smith JE, Heath LS, Skog KE, Birdsey RA (2006) Methods for calculating forest ecosystem and harvested carbon with standard estimates for forest types of the United States. Gen Tech Rep NE-343, vol 216. US Department of Agriculture, Forest Service, Northeastern Research Station, Newtown Square, p 343. https://doi.org/10.2737/NE-GTR-343

Sturtevant BR, Bissonette JA, Long JN, Roberts DW (1997) Coarse woody debris as a function of age, stand structure, and disturbance in boreal Newfoundland. Ecol Appl 7(2):702-712. https://doi.org/10.1890/1051-0761(1997)007[0702: CWDAAF]2.0.CO;2

Suzuki SN, Tsunoda T, Nishimura N, Morimoto J, Suzuki Jl (2019) Dead wood offsets the reduced live wood carbon stock in forests over 50 years after a stand-replacing wind disturbance. Forest Ecol Manag 432:94-101. https://doi. org/10.1016/j.foreco.2018.08.054

Tan B, Wu FZ, Yang WQ, He XH (2014) Snow removal alters soil microbial biomass and enzyme activity in a Tibetan alpine forest. Appl Soil Ecol 76:3441. https://doi.org/10.1016/j.apsoil.2013.11.015

Tang XL, Zhou GY (2005) Coarse woody debris biomass and its potential contribution to the carbon cycle in successional subtropical forests of southern China. Acta Phytoecol Sin 29:559-568 (in Chinese)

Taylor AH, Wei JS, Jun ZL, Ping LC, Jin MC, Jinyan H (2006) Regeneration patterns and tree species coexistence in old-growth Abies-Picea forests in southwestern China. Forest Ecol Manag 223(1-3):303-317. https://doi.org/1 0.1016/j.foreco.2005.11.010

Taylor AR, Gao B, Chen HY (2020) The effect of species diversity on tree growth varies during forest succession in the boreal forest of Central Canada. Forest Ecol Manag 455:117641. https://doi.org/10.1016/j.foreco.2019.117641

Tritton M (1981) Dead wood in the northern hardwood forest ecosystem. Yale University Press, New Haven, pp 1634-1634

Van Mantgem PJ, Stephenson NL, Byrne JC, Daniels LD, Franklin JF, Fulé PZ, Harmon ME, Larson AJ, Smith JM, Taylor AH (2009) Widespread increase of tree mortality rates in the western United States. Science 323(5913):521-524. https://doi.org/10.1126/science.1165000

Vanninen P, Ylitalo H, Sievänen R, Mäkelä A (1996) Effects of age and site quality on the distribution of biomass in scots pine (Pinus sylvestris L.). Trees 10(4): 231-238. https://doi.org/10.1007/BF02185674

Wang Q, Wang S, Fan B, Yu X (2007) Litter production, leaf litter decomposition and nutrient return in Cunninghamia lanceolata plantations in South China: effect of planting conifers with broadleaved species. Plant Soil 297(1-2):201211. https://doi.org/10.1007/s11104-007-9333-2

Wang B, Wu F, Xiao S, Yang W, Justine MF, He J, Tan B (2016) Effect of succession gaps on the understory water-holding capacity in an over-mature alpine forest at the upper reaches of the Yangtze River. Hydrol Process 30(5):692703. https://doi.org/10.1002/hyp.10613 
Wang Z, Yang W, Wu F, Chang C, Li J, Tang G, Wang Q (2017) Heavy metal absorption characteristics of epiphytic moss on coarse woody debris in an alpine forest. Acta Ecol Sin 37(9):3028-3035 (in Chinese)

Wang J, Yang Q, Qiao Y, Zhai D, Jiang L, Liang G, Sun X, Wei N, Wang X, Xia (2019) Relative contributions of biotic and abiotic factors to the spatial variation of litter stock in a mature subtropical forest. J Plant Ecol 12(4):769780. https://doi.org/10.1093/jpe/rtz018

Ward GM, Aumen NG (1986) Woody debris as a source of fine particulate organic matter in coniferous forest stream ecosystems. Can J Fish Aquat Sci 43(8): 1635-1642. https://doi.org/10.1139/f86-202

West DC, Shugart HH, Botkin DE (2012) Forest succession: concepts and application. New York: Springer Verlag, Berlin-Heidelberg Press, doi:https:// doi.org/10.1007/BF00036135, 56, 1, 44

Woodall C, Liknes G (2008) Relationships between forest fine and coarse woody debris carbon stocks across latitudinal gradients in the United States as an indicator of climate change effects. Ecol Indic 8(5):686-690. https://doi.org/1 0.1016/j.ecolind.2007.11.002

Woodall C, Walters B, Oswalt S, Domke G, Toney C, Gray A (2013) Biomass and carbon attributes of downed woody materials in forests of the United States. Forest Ecol Manag 305:48-59. https://doi.org/10.1016/j.foreco.2013.05.030

Xiao S, Wu FZ, Yang WQ, Chang CH, Li J, Wang B, Cao Y (2016) Woody debris storage and its distribution in a dark coniferous forest in the alpine-gorge area. Acta Ecol Sin 36:1352-1359 (in Chinese)

Xiong D, Zhang H, Hou R, Yi L, Fu J, Zhu Y, Jin Y (2016) Functions of coarse woody debris on water and nutrient conservation in paleo-Periglacal landform forest. Acta Bot Bor-Occid Sin 36(10):2058-2069 (in Chinese)

Yan ER, Wang XH, Huang JJ, Zeng FR, Gong L (2007) Long-lasting legacy of forest succession and forest management: characteristics of coarse woody debris in an evergreen broad-leaved forest of eastern China. Forest Ecol Manag 252(13):98-107. https://doi.org/10.1016/j.foreco.2007.06.016

Yan ER, Wang XH, Guo M, Zhong Q, Zhou W, Li YF (2009) Temporal patterns of net soil $\mathrm{N}$ mineralization and nitrification through secondary succession in the subtropical forests of eastern China. Plant Soil 320(1-2):181-194. https:// doi.org/10.1007/s11104-008-9883-y

Yang YP, Li CB, Guan ZT (1992) Forests in Sichuan. China Forestry Publishing House, Beijing (in Chinese)

Yang FF, Li YL, Zhou GY, Wenigmann K, Zhang DQ, Wenigmann M, Liu SZ, Zhang QM (2010) Dynamics of coarse woody debris and decomposition rates in an old-growth forest in lower tropical China. Forest Ecol Manag 259(8):1666-1672. https://doi.org/10.1016/j.foreco.2010.01.046

Yatskov M, Harmon ME, Krankina ON (2003) A chronosequence of wood decomposition in the boreal forests of Russia. Can J For Res 33(7):1211-1226. https://doi.org/10.1139/×03-033

Zell J, Kändler G, Hanewinkel M (2009) Predicting constant decay rates of coarse woody debris-a meta-analysis approach with a mixed model. Ecol Model 220(7):904-912. https://doi.org/10.1016/j.ecolmodel.2009.01.020

Zeng Z, Silong W, Canming Z, Zijian W, Qing H (2015) Woody debris stocks of evergreen broad-leaf forest in mid-subtropical region of China. J Biobased Material Bioenergy 9(1):37-41. https://doi.org/10.1166/jbmb.2015.1492

Zhang Y, Duan B, Xian J, Korpelainen H, Li C (2011) Links between plant diversity, carbon stocks and environmental factors across a successional gradient in a subalpine coniferous forest in Southwest China. Forest Ecol Manag 262(3): 361-369. https://doi.org/10.1016/j.foreco.2011.03.042

Zhang K, Cheng X, Dang H, Ye C, Zhang Y, Zhang Q (2013) Linking litter production, quality and decomposition to vegetation succession following agricultural abandonment. Soil Biol Biochem 57:803-813. https://doi.org/10.1 016/j.soilbio.2012.08.005

Zhu J, Hu H, Tao S, Chi X, Li P, Jiang L, Ji C, Zhu J, Tang Z, Pan Y (2017) Carbon stocks and changes of dead organic matter in China's forests. Nat Commun 8(1):1-10. https://doi.org/10.1038/s41467-017-00207-1

Ott L, Mann P. Van Cleve K (2006) Successional processes in the Alaskan boreal forest. In: Chapin FS, Oswood MW, van Cleve K, Viereck LA, Verbyla DL (eds) Alaska's changing boreal forest. Oxford: Oxford University Press, pp 100-119

\section{Submit your manuscript to a SpringerOpen ${ }^{\circ}$ journal and benefit from:}

- Convenient online submission

- Rigorous peer review

- Open access: articles freely available online

- High visibility within the field

- Retaining the copyright to your article

Submit your next manuscript at $\boldsymbol{\nabla}$ springeropen.com 